\title{
ONLINE TESTS IN LANGUAGE TEACHING
}

\author{
Helena Neumannová ${ }^{1}$ \\ ${ }^{1}$ Technická univerzita v Liberci, Ekonomická fakulta, Studentská 2, 46117 Liberec 1 \\ Email:helena.neumannova@tul.cz.
}

\begin{abstract}
Training online can improve attainment and a deepening of knowledge of subject matters in all of the four skills (speaking, reading, writing, listening). Also, students are motivated to improving their knowledge. The format of the test and the possibility of a quick and precise evaluation is another advantage, making the online method attractive. The students of the Technical University Liberec can train another competence this way which is reading. The geographic position of the Liberec region and the existence of the Euro-region Neisse practically predestine the co-operation extending beyond the borders of the country. In this region, job offers are mainly made by German entrepreneurs and companies.
\end{abstract}

Keywords: autonomous learning, feedback, language computer programs, motivation of the students, selection of tests, tests on the internet.

JEL classification: A1

Doručeno redakci: 28.6.2011; Recenzováno: 12.2.2013; 17.2.2013; Schváleno k publikování: 16.4.2013

\section{Introduction}

With the development of New technology, there is a continuous emphasis placed on selfstudy in the form of preparing students and teacher training through the assistance of electronic or New Media. In addition to other aspects, it is also obviously connected with higher education politics in the Czech Republic, where it is easy to make access to education available to as many students as possible and at the same time move actual teaching to an extracurricular environment in which students have the opportunity to study based on their available time and interest. With the help of computer programs, it is possible to train all four language competencies: listening, writing, reading and speaking. They can be practiced by suitable programs and appropriately composed tasks (working with the internet, tandem learning on the internet, work with web pages, email activities, project tasks, etc.).

\section{Foreign Language Study and Current Trends}

Current study methods promote autonomous learning through which the student controls his or her learning process independently pursuing and checking the material that has been mastered. This form of self-study also makes possible, for example, various language computer programs, with which the student is able to select the activity's theme and level of difficulty. With the aid of feedback the acquired level is verified independently; after successfully completing one step, the student proceeds to a more difficult task.

Foreign language study from this perspective has a wealth of possibilities, for example, assisted by online methods for testing, it is possible to attain effective results through practicing and extending skills in all four language competencies which motivates students to further perfect their knowledge. Access to tests along with a quick and accurate evaluation of their results is another advantage that makes online methods for the study of foreign languages attractive (Vlčková, 2009). The main use of the computer for studying a foreign language, however, primarily consists of training and retaining vocabulary and grammar.

In the Department of Foreign Languages at the Technical University of Liberec (TUL) during the period from 2006 to 2011 with the support of projects driven by Higher Education 
Development Funds (HEDF), an extensive online database of exercises was created for studying German. The origin of this database is the result of work carried out by teachers and students who contributed to the selection of tests and their implementation into a test module. It consists of online exercises focused on the practice of grammar, reading comprehension, listening comprehension, and, newly from 2011, writing skills. The grammatical section consists of semantic and translation exercises, exercises in morphology, syntax and lexicology, and each grammatical feature contains about 1000 examples. Based on their needs, students can generate tests on their own selecting features in which they have obvious gaps and would like to practice.

In recent years there has been a tendency to study in the combined / distance form and the numbers of students who study and work at the same time have constantly been increasing. See Chart No.1.

Table 1: Numbers of students in the combined study at the Economical Faculty of the Technical University (EF TUL) In the academic years 2007/2008 and 2010/2011* - comparison

\begin{tabular}{|c|c|c|c|c|c|c|c|}
\hline Field of study & Year 1 & Year 2 & Year 3 & Year 4 & Year 5 & Year 6 & TOTALS \\
\hline \multicolumn{8}{|c|}{$\begin{array}{l}\text { REGULAR STUDENTS } \\
\end{array}$} \\
\hline $\begin{array}{l}\text { Business } \\
\text { Administration }\end{array}$ & $\begin{array}{c}223 / 15 \\
0\end{array}$ & $161 / 144$ & $114 / 172$ & $/ 198$ & $/ 195$ & $-1-$ & $498 / 859$ \\
\hline Foreign Trade & $81 / 94$ & $56 / 105$ & $21 / 90$ & $12 / \mathbf{1}$ & $-/-$ & $-/-$ & 170/290 \\
\hline $\begin{array}{l}\text { Economics and } \\
\text { Service } \\
\text { Management }\end{array}$ & $-/ 72$ & & & & & & $-/ 72$ \\
\hline Tourism & $-/ 82$ & & & & & & $-/ 82$ \\
\hline $\begin{array}{l}\text { Insurance } \\
\text { Business }\end{array}$ & $34 / 11$ & $23 / 9$ & $21 / \mathbf{1 1}$ & $/ 17$ & $-/ 22$ & $-/-$ & 78/70 \\
\hline $\begin{array}{l}\text { Business } \\
\text { Informatics }\end{array}$ & $20 / 34$ & $25 / 26$ & $/ 10$ & $1 / 23$ & $-/ 26$ & $1 /-$ & $46 / 120$ \\
\hline $\begin{array}{l}\text { NISA } \\
\text { University }\end{array}$ & $15 / \mathbf{1 6}$ & $20 / \mathbf{1 3}$ & $34 / 17$ & $-/-$ & $-/-$ & $-/-$ & $69 / 46$ \\
\hline Totals & $\begin{array}{c}373 / 45 \\
9\end{array}$ & $285 / 297$ & 190/300 & $13 / 239$ & $-/ 243$ & $-/ 1$ & $861 / 1539$ \\
\hline \multicolumn{8}{|c|}{ DISTANCE STUDENTS } \\
\hline $\begin{array}{l}\text { Business } \\
\text { Administration } \\
\text { Liberec }\end{array}$ & $57 / 60$ & $30 / 39$ & $38 / 54$ & $30 / 115$ & $-/-$ & $-/-$ & $155 / 420$ \\
\hline $\begin{array}{l}\text { Business } \\
\text { Administration } \\
\text { Jičín }\end{array}$ & $16 / 22$ & $17 / 10$ & $23 / 14$ & $-/-$ & $-/-$ & $-/-$ & $56 / 46$ \\
\hline Č. Lípa & $14 / \mathbf{1 7}$ & $29 / 26$ & $-/ / 14$ & $-1-$ & $-1-$ & $-1-$ & $43 / 57$ \\
\hline Totals & $87 / 99$ & $76 / 75$ & $61 / 82$ & $30 / 115$ & $-/ 127$ & $-/ 25$ & $254 / 523$ \\
\hline EF TUL totals & $\begin{array}{c}460 / 55 \\
8\end{array}$ & $361 / 372$ & $251 / 382$ & $43 / 354$ & $-/ 370$ & $-/ 26$ & $1115 / 2062$ \\
\hline
\end{tabular}

Source: internal materials of EF TUL

This chart shows quite clearly the increase of the amount of students in the combined form of study within last three years. However, the combined form of study puts higher demands both on teachers and students - their preparation for lessons is focused strongly on autonomous learning and independent training. Teaching methods on the teachers' part require more emphasis on the mediation of communicative competences, and that is why the use of online tests in foreign language teaching appears very effective. 
A more detail specification and categorization of the term 'test' is described by Peter Doyé: "Der Ausdruck TEST wird in diesem Buch im weitesten Sinne verstanden und umfaßt somit alle Arten der Prüfung von Leistungen unabhängig von ihrer Form, ihrer Länge, ihrem Verwendungszweck und dem Grad ihrer Formalisierung. ... Wir halten uns statt dessen an den Gebrauch des Wortes "Test" in der englischen Sprache, der es ja schließlich entnommen ist, und meinen damit alle Prüfverfahren, in welchen die Probanden durch bestimmte Aufgaben zu einem Verhalten veranlaßt werden, aus dem man auf Persönlichkeitsmerkmale - im Fremdsprachenunterricht: sprachliche Kompetenzen - dieser Probanden schließen kann..." (Doyé, 1992).

With the help of computer programs and appropriately set exercises there can be practiced all language skills: listening, writing, reading comprehension and speaking (work on the Internet, partner teaching with the help of the Internet, work with Internet pages, e-mail exercises, project assignments etc.) Nevertheless, the center of the computer assisted teaching still lies in training and expanding vocabulary and grammar.

A graduate of the Economical Faculty of TUL should be able to work with specialized foreign language texts, and he/she should be able to master basic vocabulary in all important fields of economy without big difficulties. In the way of training these competences, the use of the testing module which stresses independent student preparation seems to be ideal.

\section{Bussines German Teaching}

On the basis of the cooperation of the Department of Foreign Languages within the School of Economics and the Department of Applied Mathematics within the School of Natural Sciences-Humanities and Education, the system was created enabling the database of exercises to be placed on the TUL server.

In the introduction is the so called "Zero Lesson". Here you will find

- HEvinky / Neuigkeiten Fórum (News)

- Whlovník pojmů / Wörterbuch der Begriffe (Dictionary of Terms and Important Phrases)

- Dîležležité vazby a spojení / Wichtige Rektionen und Verbindungen Slovník (Collocations containing vocabulary of expressions and phrases)

- OTesty z gramatiky / Grammatikteste soubor (Grammatical Tests)

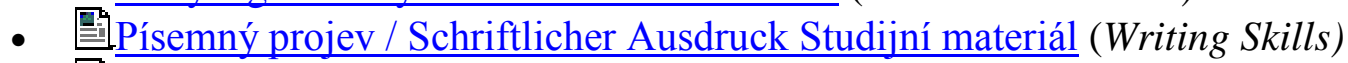

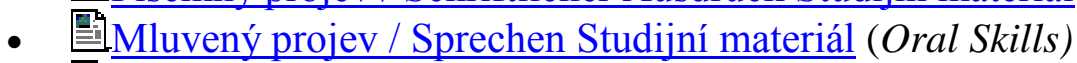

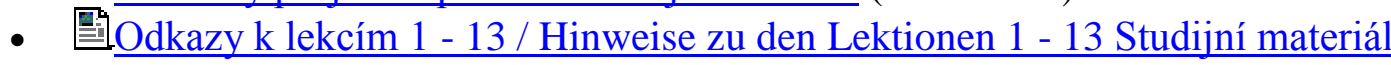
(References to Lessons 1-13)

- $\square \underline{\text { Soubor textů/Textordner (Textfile) }}$

the Dictionary of Terms and Important Phrases and Collocations containing vocabulary of expressions and phrases which appear in the texts of lessons 1-13. The Grammatical Tests contain exercises in the range of A1-B1 of the Common European Framework of References for Languages (CEFR), the Writing Skills consist of activities dealing with administrative and business correspondence, the Oral Skills enable the practice of phrases for presentations, discussions and argumentation. The References to Lessons 1-13 provide information for significant websites where further exercises can be found. 
The content of lessons 1-13 reflect the thematic content in the syllabi for the programs of study in the Department of Foreign Languages at TUL and provide supplementary material for teaching.

$1 \quad$ Werbung, Messen, Ausstellungen (Publicity, fairs, exhibitions)

$2 \quad$ Handel (Trade)

3 Import, Export (Import, Export)

$4 \quad$ Banken (Banks)

5 Datenverarbeitung (Data processing)

$6 \quad$ Transport und Verkehr (Transport and traffic)

7 Tourismus (Tourism)

8 Landwirtschaft (Agriculture)

9 Energie, Industrie, Arbeitswelt (Energy, industry, work environment)

10 Konjunktur, Währung, Börse, Haushalt, Steuern (Economic cycle, currency, stock market, budget, taxes)

11 Studium, Universität (Study, university)

12 Europäische Union (The European Union)

13 Zukunftsperspektiven und Zukunftstechnologien, Lebensstil, Gesundheitspflege, Umwelt (Future prospects, future technologies, life style, health care, environment)

Figure 1: Sample of Exercise in the Test Module

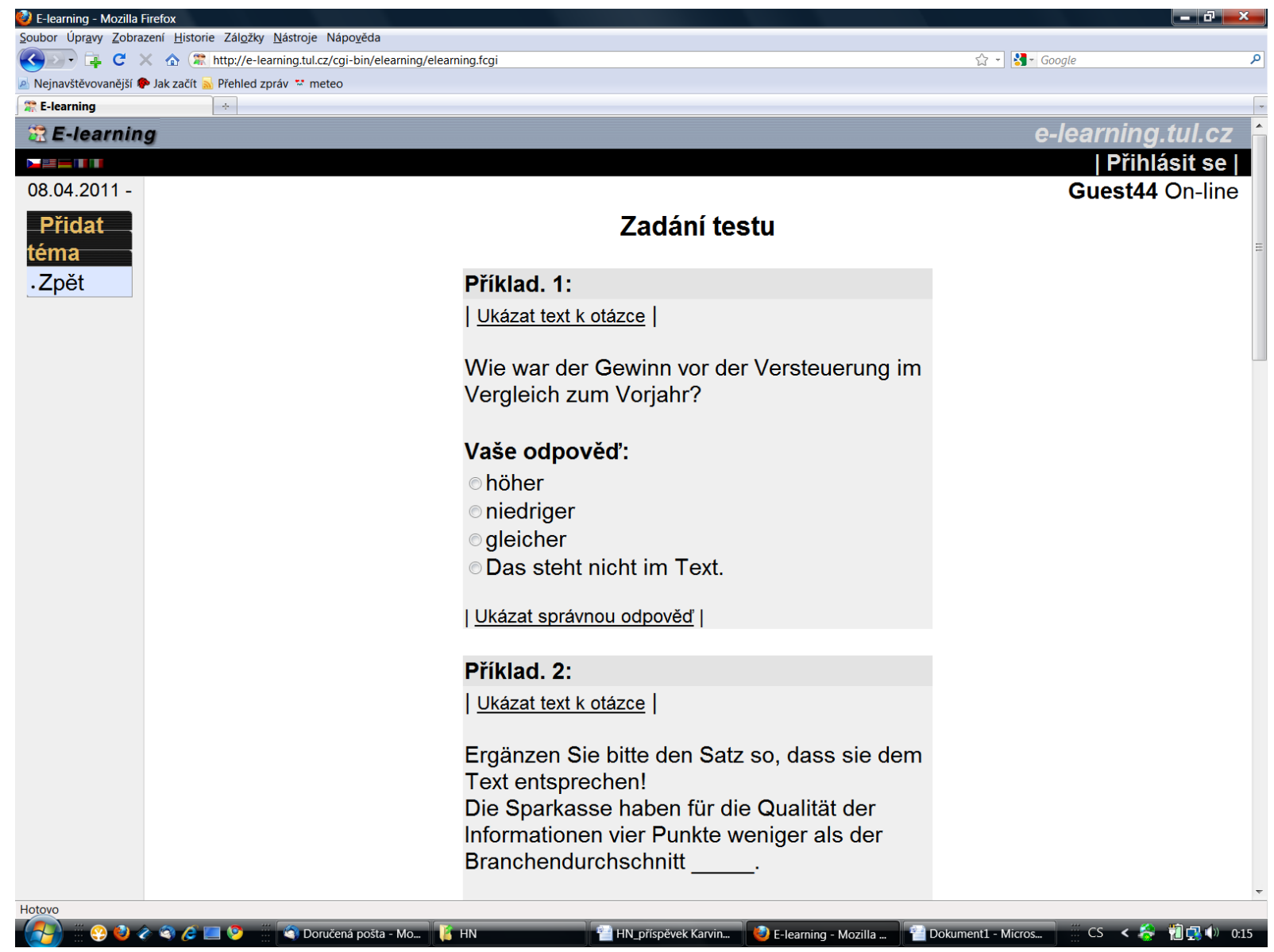

Source: http://e-learning.tul.cz 
It is expected that the student will be motivated by working with online tests for the following reasons and will perceive the exercises as an opportunity for:

$\checkmark$ supplementary practice (when the tempo of the course is too slow),

$\checkmark$ reinforcing and extending material (when the tempo of the course is too fast),

$\checkmark$ study of missed material (following illness, holidays, etc.),

$\checkmark$ repetition of what was just learned and then forgotten

The advantages of working with online tests in comparison with traditional testing is:

$\checkmark$ higher motivation of students = greater success in learning,

$\checkmark$ precision of evaluation - the PC accepts only correct answers,

$\checkmark$ possibility for repetition - exercises may be repeated at any time,

$\checkmark$ selection of exercises with progressive difficulty

$\checkmark$ unlimited access to tests at any time,

$\checkmark$ great variety/number of examples,

$\checkmark$ removing fear of incorrect responses - anonymity during work with the PC (the student is not required to answer to the teacher nor to other students).

\section{Conclusion}

The system of parameterized language tests and exercises is operated by the LINUX server and is accessible through the Internet. The system is built on HTML-technology, using the SQL database system and the PERL program language. The classical method of training grammar has been extended to include alternative methods which contribute to learning autonomy and are fully consistent with the conceptualization for preparing students at university. The accessibility of tests in electronic form should contribute to the effectiveness of the classroom process from the student's side along with improving the quality of teaching German in the Department of Foreign Languages.

The test module can be used within the framework of preparing for instruction not only by students of TUL, but also by instructors of German who may draw on support material here for their teaching. The link to tests is also accessible on the German language web pages at http://turbo.cdv.tul.cz/.

\section{References}

[1] DOYÉ, P., 1992. Typologie der Testaufgaben für den Unterricht Deutsch als Fremdsprache. 1. vyd. Berlin/München/Wien/Zürich/NewYork: Langenscheidt, 223 s.

[2] MERTENS, M., 2010. Übungsblätter per Mausklick. CD-ROM. München: Hueber Verlag Gmbh \& Co K.

[3] NEUMANNOVÁ, H., 2005. Typologie testových úloh ve výuce německého jazyka. In Ekonomické a lingvistické aspekty spolupráce. 1. vyd. Liberec: Technická univerzita v Liberci, s. 42. ISBN 80-7083-928-7.

[4] Neue Medien im Deutschunterricht, Fremdsprache Deutsch, Heft 21, Klett Verlag München, 2002. ISBN 3-88246-059-8.

[5] Testovaci server [online]. Dostupný z WWW:

<http://turbo.cdv.tul.cz/course/view.php?id=7>

[6] VLČKOVÁ, I., 2009. Multimedialer Sprachenunterricht an der TU in Liberec. In Liberecké ekonomické fórum 2009. 1. vyd. Liberec: Technická univerzita v Liberci, s. neuvedeny (6 stran). ISBN 978-80-7372-5013. 